\title{
How Does Guided Inquiry Enhancing Students' Mathematical Literacy? An Experimental Study for Mathematics Learning
}

\author{
${ }^{1}$ Luthfi Nur Azizah \& ${ }^{2}$ Ali Mahmudi \\ ${ }^{1}$ Department of Mathematics Education, Graduate School, Universitas Negeri Yogyakarta \\ ${ }^{2}$ Faculty of Mathematics and Science, Universitas Negeri Yogyakarta \\ ${ }^{1}$ Luthfinurazizah.2017@student.uny.ac.id
}

\begin{abstract}
This paper reports a quasi-experimental study with one group pre-test post-test design on promoting mathematical literacy using guided inquiry method. As one of the important education goals globally, mathematical literacy focuses on a concrete dimension with context and content to be studied. A total of 32 secondary school students of class VIII participated as a sample and 192 students as a population in the study. Students' mathematical literacy was measured by using an essay test. The students' responses were analysed and compared using paired sample t-Test. It was found that the guided inquiry method successfully promotes students' mathematical literacy as indicated by the result of paired sample t-test values of significance (2-tailed) of $0.000<0.05$. Thus, the guided inquiry can be used as an alternative learning method to improve students' mathematical literacy.
\end{abstract}

Keywords: guided inquiry, mathematical literacy, quasi-experimental.

\section{Introduction}

One of the goals of today's education is to prepare students to apply the knowledge they have in everyday life. This is in line with Moretti and Frandell's (2013) opinion, which stated that education has roles in preventing risks and a tool that can improve the quality of human life. Mathematical literacy helps someone recognise the role of mathematics and assess it to make decisions that a constructive, active, and reflective citizen needs (OECD, 2017). In addition, the results of research conducted by Higo, Wada, and Sato (2012) showed that students who have good mathematical achievement have good mathematical literacy skills. In fact, students' mathematical literacy skills in Indonesia are still low and far below the average. This can be seen from the results of PISA 2009, PISA 2012, and PISA 2018 which revealed that more than $75 \%$ of Indonesian students were only able to work up to level 2 (OECD, 2010; 2014; 2019)

According to Khoirudin, Setyawati, and Nursyahida (2017), low mathematical literacy skills are influenced by learning process at school, classroom environment, support for the family environment, test readiness and implementation, and abilities of each student. School mathematics learning needs to be designed by teachers in situations where students are active in every learning activity. Therefore, traditional learning is not the right alternative for designing learning activities. There are several learning methods and strategies that can be applied to make students more active in learning activities. As the opinion of Khan (2012, p.1) which states that "educationists suggest various student-centred strategies for making students more autonomous in the learning process". Therefore, various student-centred 
learning strategies are highly recommended to make students explore mathematics independently during the learning process.

There is one of the learning methods that can be used in mathematics learning, namely inquiry-based learning. The inquiry comes from the word to inquire, which means participating or being directly involved in asking questions, seeking information, and conducting investigations (Kuhlthau, Maniotes, \& Caspari, 2007). Kuhlthau et al. (2007) define inquiry-based learning as a learning approach in which students find and use various sources of information and ideas to increase their understanding of a particular problem or topic. This approach is not only about answering a question or getting the right answer, but also requires investigation, exploration, search, research, pursuit, and study. This is also emphasised by Duran \& Dökme (2016) that describe inquiry-based learning as a way of asking questions, seeking information and finding new ideas related to an event. Furthermore, inquiry-based learning supports students in applying students' knowledge, understanding realworld situations and reinforcing the discovery process.

There are two types of inquiry-based learning: guided inquiry and open inquiry (Jiang \& Mc Comas, 2015). Furthermore, Colburn (2000) classified inquiry into structured inquiry, guided inquiry, and open inquiry. The structured inquiry is a learning activity in which the teacher gives students direct problems to investigate, procedures, and materials, but does not tell them about the expected results. Students must find relationships between variables or generalise from the data collected. This inquiry type usually includes more directions than structured inquiry activities into what students should observe and what data they should collect. Guided inquiry is a learning activity where the teacher only provides material and problems to be investigated. Students design their own procedures for solving problems. Open inquiry is likely a guided inquiry, with the addition that students also formulate their own problems to be investigated.

In essence, the types of inquiry that have been previously disclosed are not much different. The difference between each type is only whether assistance is provided in the form of questions or problems (hypotheses), completion procedures or instructions, and solutions at each of these types. Then, for the steps in inquiry, learning is not different at each type. This study uses guided inquiry in mathematics learning in schools. The steps in guided inquiry are formulating problems, submitting hypotheses, collecting data, testing hypotheses, drawing conclusions, implementing, and following up.

\section{Methods}

This research is a quasi-experimental research with one group pre-test post-test design. This research used one group of students without any control group with type one group pretest post-test design (Privitera \& Ahlgrim-Delzell, 2018). This study's population was the entire class VIII in SMPN 2 Sleman, which consists of 6 classes. Random sampling technique was used and resulted in class VIII D as a sample with 32 students. The instrument used in measuring mathematical literacy skills in this study is an essay test. 


\section{Results and Discussion}

The implementation of learning with the guided inquiry method was assessed based on observations from two professional observers in mathematics learning during four meetings. The learning implementation observation sheet contains a set of statements that refer to the guided inquiry method steps. The scale used is the Guttman Scale with two options, yes or no. The learning results with the guided inquiry method showed the average percentage when viewed from teacher activities was $97 \%$, and student activities were $92 \%$. This shows that mathematics learning with the guided inquiry method has been carried out well.

As for the pre-test and post-test results, students' mathematical literacy abilities can be seen in Table 1 below.

Table 1

Results of the Mathematical Literacy Test

\begin{tabular}{cclcc}
\hline $\begin{array}{c}\text { Process } \\
\text { Components }\end{array}$ & \multicolumn{2}{l}{ Indicator } & \multicolumn{2}{c}{ Type of Test } \\
Formulate & 1. & Selecting relevant information & 52 & 92,7 \\
& 2. & Preating a mathematical model & 31 & 81,3 \\
\multirow{2}{*}{ Employ } & 3. & Using mathematical formulas or concepts & 54 & 80,5 \\
& 4. & Determining a mathematical solution & 37 & 65,2 \\
\multirow{2}{*}{ Interpret } & 5. Interpreting mathematical solutions & 9,4 & 54,7 \\
& 6. & Giving reasons & 9,4 & 54,2 \\
\hline \multicolumn{2}{c}{ Overall Average } & & 39,1 & 74,8 \\
\hline
\end{tabular}

Based on Table 1, the students' pre-test score of mathematical literacy skills in that class has not yet reached the minimum score of 70 . However, after being given treatment, there was an improvement in the students' mathematical literacy skills. The class's average score using the guided inquiry method learning increased by 35.7, from an initial score of 39.1 to 74.8 . It can also be seen that the indicator related to the use of mathematical formulas or concepts have the highest average score compared to other indicators. This means that students know the right mathematical formula or concept to solve the problem, but still make mistakes in performing calculations or determining mathematical solutions. Furthermore, for the interpretive process component, which is divided into two indicators, namely interpreting the mathematical solution into the context of the problem and providing the right reasons based on the mathematical solution, both of the average scores are 9.4. This score is the lowest compared to the other indicators. Most students made mistakes in interpretation and did not provide reasons based on the answers obtained correctly.

Inquiry-based learning supports students in applying students' knowledge, understanding real-world situations and supports the discovery process (Toth, Ludvico, \& Morrow, 2014). The research results conducted by Wang, Rodr, Maxwell, and Algar (2016) found that guided inquiry learning can improve students' understanding of the concept and increase students' research skills. The learning step using the guided inquiry begins with presenting the problems and asks students to formulate the problems. After that, students are asked to submit hypotheses to solve these problems. This activity asks students to provide a provisional guess on how to solve the problems presented. 
Furthermore, students are asked to collect the necessary data to solve the problem based on predetermined assumptions through various sources. This activity of formulating problems, proposing hypotheses, and collecting data can help students develop the formulation process skills in mathematical literacy. This is because there is a process of formulating and recognising or identifying the problems given. The next activity is to test hypotheses using data that has been previously collected, which in this case are concepts, facts, and mathematical procedures that have been adjusted to the previous expectations. This activity allows students to develop skills in the process of employing process components in mathematical literacy. Then, students are asked to conclude the results of the hypothesis that have been tested. After that, students are allowed to apply and follow up on the concepts that have been found previously.

In this final step, students are expected to explain their understanding of the concepts and processes that have been obtained, which are then allowed to apply these concepts in the new contexts or situations to develop a deeper understanding. This is possible to develop the ability to interpret mathematical literacy processes. This interpretive process refers to interpreting and reflecting mathematical solutions or conclusions obtained into the context of the problem. The sample about mathematical literacy problems is as follows.

\section{Context: Scientific (Revolving Door)}

A revolving door with 3 door wings, rotating in a circle. The three wing doors divide the space into three equal areas. The image below shows the wing doors in three different positions when viewed from above.

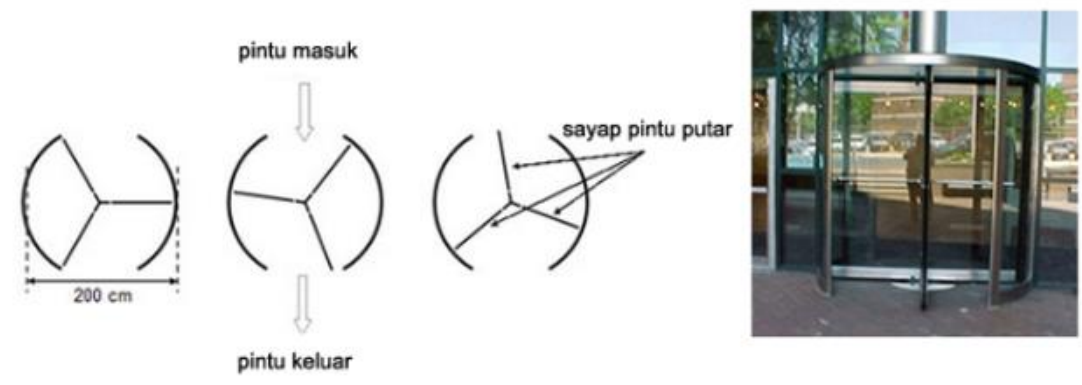

a. What is the size of the corner formed by the two wings of the door?

b. If the door rotates 4 times in 1 minute and the maximum capacity of each door space is entered by 2 people, what is the maximum number of people who pass through the door in 30 minutes?

Figure 1. Sample of mathematical literacy problems.

The problem in Figure 1. belongs to the process component, namely formulate and employ. In this problem, students are asked to select relevant information to solve problems, create mathematical models, use mathematical formulas or concepts appropriately, and determine mathematical solutions. The following is a sample of student's pre-test response. 


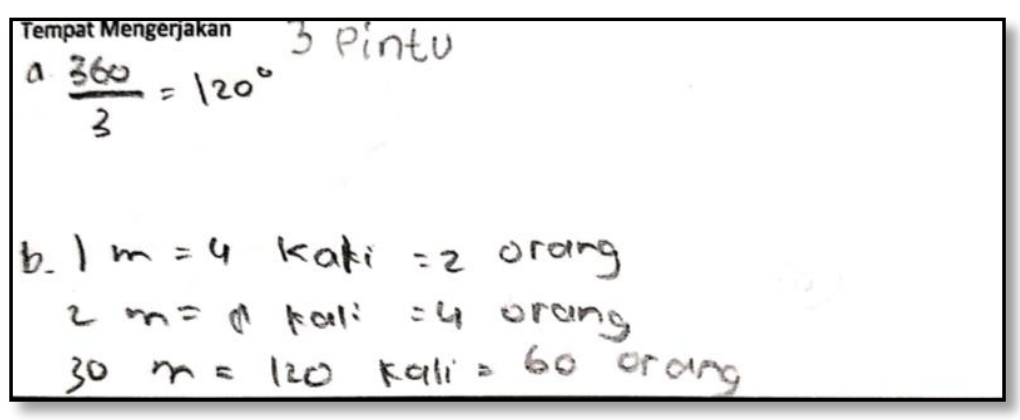

Figure 2. Sample of student's pre-test response.

Figure 2 shows that the student has used mathematical concepts to solve the problem in number 1a and do the calculations correctly. For problem number $1 \mathrm{~b}$, the student still has not chosen the relevant information yet, because he thought that four-door turns only contain a maximum of 2 people. Besides, the student has not tried to make a mathematical model based on the problem, so that the score obtained was not optimal.

The post-test results of students' mathematical literacy abilities showed a significant increase in scores for each component of the mathematical literacy process. Even though there were still some students' errors in answering the problems. Most students are good at writing down relevant information to solve problems, but they still make mistakes when making mathematical models. Besides that, students could use the mathematical formulas or concepts correctly, but some students still make mistakes in calculations or determine the mathematical solutions. Then, in terms of interpreting the solution, some students answered correctly, but some still had difficulties interpreting the mathematical solution correctly. The result of miscalculation and interpretation of mathematical results or solutions is that students were not precise in providing reasons for the answers so that their scores are not optimal.

The following sample of mathematical literacy problem for components of the employ and interpret process can be seen below.

\section{Context: occupational (Fostering a Garden)}

A garden shaped like the picture on the side will be fertilized. Every $100 \mathrm{~m} 2$ requires $1.5 \mathrm{~kg}$ of fertilizer. If $5 \mathrm{~kg}$ of fertilizer is available, will it cover the entire garden area?

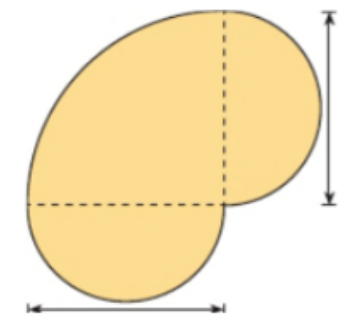

Figure 3. The sample of mathematical literacy problem for components of the employ and interpret process.

The problem asks students to use the right mathematical formula or concept to solve the problem and determine the mathematical solution. The mathematical concept that students need to solve this problem is the concept of a circular area. Then, from the predetermined concept, students are asked to determine the solution. Then, the solutions are interpreted into 
the context of the problem being asked, namely determining the adequacy of fertilisers that must be used. Furthermore, from the student's interpretation, questions are given about the reasons for the student's answer. If students do this series of steps correctly, they will get the maximum score. The snippets of student' post-test responses can be seen in Figure 4 below.

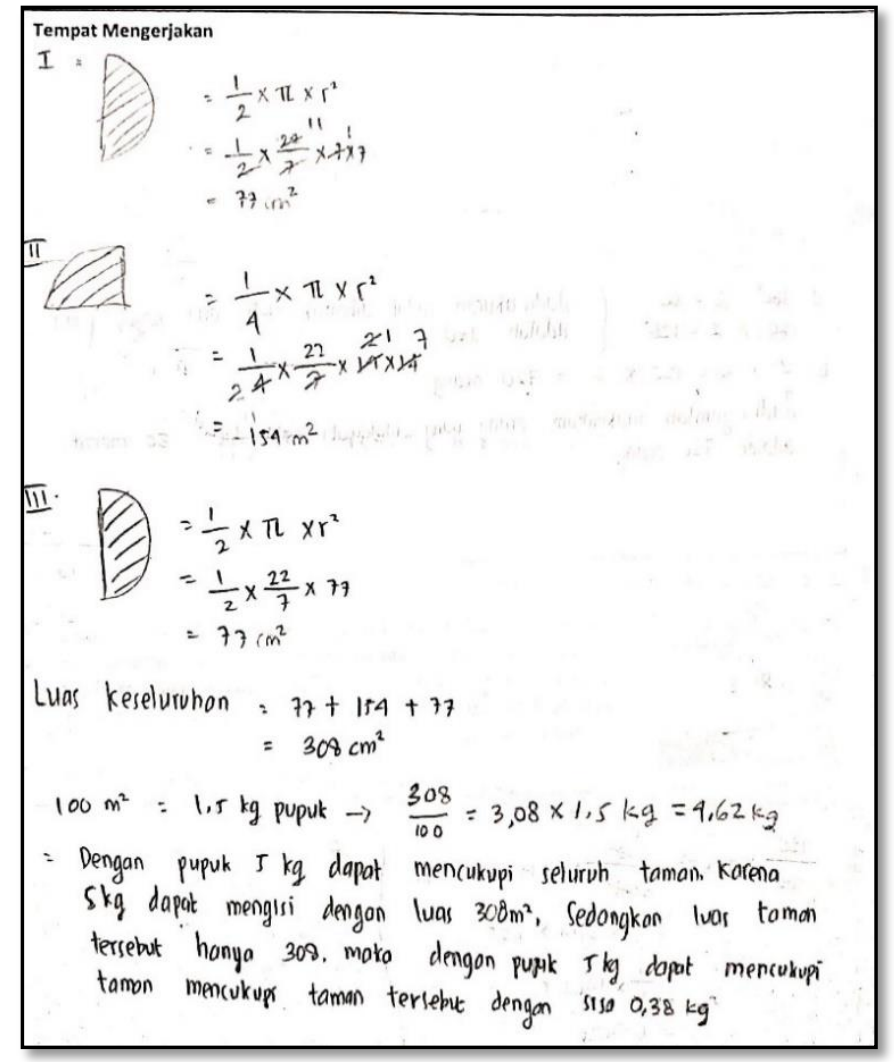

Figure 4. Sample of student's post-test response.

Based on the results of the student's response in Figure 4, it can be seen that the student has used the right mathematical formula or concept to solve problems and determine mathematical solutions. Then the student determines the amount of fertiliser needed by interpreting the answers obtained in the context of the problem. Next, he gave the exact reasons for the questions given. Thus, the student gets the maximum score.

Furthermore, based on the results of descriptive analysis, it can be seen that the average score of students' mathematical literacy skills has increased, this is because in the guided inquiry method there are several learning steps such as formulating problems, proposing hypotheses, collecting data, testing hypotheses, drawing conclusions, and applying and following up. After the teacher conveys the learning objectives, it is followed by giving students motivation to be actively involved in the problem-solving process. The guided inquiry learning method is also closely related to providing real-world problems as a source of student learning. This certainly can develop a component of the process, namely the formulate in mathematical literacy skills.

When viewed in inferential statistics, the post-test univariate normality assumption test of students' mathematical literacy abilities shows a Kolmogorov-Smirnov significance value of $0.68>0.05$ can be concluded that the data comes from a normally distributed population. Based on the Test of Homogeneity of Variances' results, the significance value of the post- 
test of mathematics literacy is $0.282>0.05$, so it can be concluded that the two-sample data come from populations that have the same variance. Furthermore, the inferential analysis was carried out to determine the average difference before and after treatment was given. The results of the average difference test analysis according to paired sample t-Test with the help of IBM SPSS Statistics 21 software shows that significance (2-tailed) of $0.000<0.05$. It means that guided inquiry method successfully promotes students' mathematical literacy.

This result is in line with Sulistyowaty and Prafianti (2017) and Matthew \& Kenneth (2013) which reveal that this method can improve student achievement. One of the students' achievements in learning mathematics is mathematical literacy ability. These results also align with the opinion from Kuster, Johnson, Keene, and Andrews-larson (2017) that inquiry learning allows students to be actively involved, and students have a commitment to active learning in class. This is also emphasised by Ural (2016) that in an inquiry-based learning environment, students are more active, and they guide their own learning process. Besides, the research results from Hassi and Laursen (2015) support that learning mathematics in a classroom situation that uses student activity, deep involvement, and collaboration can improve not only students' thinking skills but also their abilities in problem-solving. Furthermore, research conducted by Duran and Dökme (2016) also reveals that mathematical literacy related to providing real-world problems can help students build their critical thinking skills.

\section{Conclusion}

Based on the research, we found that the guided inquiry method effectively enhances students' mathematical literacy skills. Therefore, to improve mathematical literacy skills, teachers should provide students with clear guidance in the activities. Teachers also need to remind students of the initial purpose of the inquiring carried out because the objectives are closely related to the conclusions.

\section{References}

Colburn, A. (2000). An Inquiry Primer. Science Scope, 23(6), 42-44. Retrieved from https://eric.ed.gov/?id=EJ612058

Duran, M., \& Dökme, I. (2016). The effect of the inquiry-based learning approach on student's critical-thinking skills. Eurasia Journal of Mathematics, Science and Technology Education, 2887-2908. https://doi.org/10.12973/eurasia.2016.02311a

Hassi, M., \& Laursen, S. L. (2015). Transformative Learning: Personal Empowerment in Learning Mathematics. Journal of Transformative Education, 13(4), 316-340. https://doi.org/10.1177/1541344615587111

Higo, A., Wada, Y., \& Sato, Y. (2012). Exploring the relationship between Iranian students' Mathematical Literacy and Mathematical performance. Journal of American Science, 59(11), $562-571$. Retrieved

from https://www.jstage.jst.go.jp/article/nskkk/59/11/59_562/_pdf 
Jiang, F., \& Mc Comas, W. F. (2015). International Journal of Science the Effects of Inquiry Teaching on Student Science Achievement and Attitudes: Evidence from Propensity Score Analysis of PISA Data. International Journal of Science Education, 37-41. https://doi.org/10.1080/09500693.2014.1000426

Khan, A. W. (2012). Inquiry-based teaching in mathematics classroom in a lower secondary school of Karachi, Pakistan. International Journal of Academic Research in Progressive Education and Development, 1(2), 1-7. Retrieved from http://ecommons.aku.edu/pakistan_ied_pdcc/7

Khoirudin, A., Setyawati, R. D., \& Nursyahida, F. (2017). Profil Kemampuan Literasi Matematika Siswa Berkemampuan Matematis Rendah dalam Menyelesaikan Soal Berbentuk PISA. Aksioma, 8(2), 33-42. https://doi.org/10.26877/aks.v8i21839

Kuhlthau, C. C., Maniotes, L. K., \& Caspari, A. K. (2007). Guided Inquiry: Learning in the 21th Century. London: Libraries Unlimited.

Kuster, G., Johnson, E., Keene, K., \& Andrews-larson, C. (2017). Inquiry-oriented instruction: A conceptualisation of the instructional principles. PRIMUS, 1970(August). https://doi.org/10.1080/10511970.2017.1338807

Matthew, B., \& Kenneth, I. O. (2013). a Study on the Effects of Guided Inquiry Teaching Method on Students Achievement in Logic. International Researcher, 2(1), 135-140.

Moretti, G. A. S., \& Frandell, T. (2013). Literacy from a Right to Education Perspective.

OECD. (2019). PISA 2018 (Volume 1): What Students Know and Can Do. Retrieved from https://www.oecd-ilibrary.org/education/pisa-2018-results-volume-i_5f07c754-en.

OECD. (2017). PISA for Development Assessment and Analytical Framework: Reading, Mathematics and Science, Preliminary Version (Preliminary). Paris: OECD Publishing.

OECD. (2014). PISA 2012 Result in focus: What 15-year-olds know and what they can do with what they know. Retrieved from http://www.oecd.org/pisa/keyfindings/pisa-2012results.htm.

OECD. (2010). PISA 2009 results: Vols. $I-V$. Retrieved from https://www.oecd.org/pisa/pisaproducts/pisa2009keyfindings.htm

Privitera, G. J., \& Ahlgrim-Delzell, L. (2018). Research methods for education. New York, NY: Sage Publishing.

Sulistyowaty, R. K., \& Prafianti, R. A. (2017). Implementation of Inquiry Strategy on Exponent, Roots and Logarithm Implementation of Inquiry Strategy on Exponent, Roots and Logarithm. Journal of Physics: Conference Series PAPER, 1-5. https://doi.org/doi :10.1088/1742-6596/895/1/012078

Toth, E. E., Ludvico, L. R., \& Morrow, B. L. (2014). Blended inquiry with hands-on and virtual laboratories: the role of perceptual features during knowledge construction. Interactive Learning Environments, 22(5), 614-630. https://doi.org/10.1080/10494820.2012.693102 
Ural, E. (2016). The Effect of Guided-Inquiry Laboratory Experiments on Science Education Students' Chemistry Laboratory Attitudes, Anxiety and Achievement. Journal of Education and Training Studies, 4(4), 217-227. https://doi.org/10.11114/jets.v4i4.1395

Wang, J. J., Rodr, J. R., Maxwell, E. J., \& Algar, W. R. (2016). Build Your Own Photometer: A Guided-Inquiry Experiment to Introduce Analytical Instrumentation. Journal of Chemical Education, 93, 166-171. https://doi.org/10.1021/acs.jchemed.5b00426 
96 Southeast Asia Mathematics Education Journal, Volume 10, No 2 (2020) 